\title{
Intestinal parasites, including Cryptosporidium species, in Iraqi patients with sickle-cell anaemia
}

N.K. Mahdi and N.H. Ali

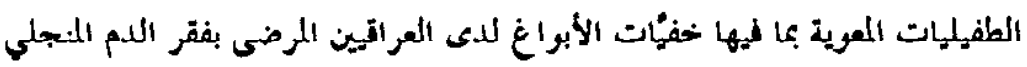

$$
\begin{aligned}
& \text { ناظم كاطم مهيدي، نائل حسـن عليه }
\end{aligned}
$$

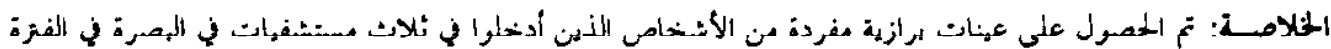

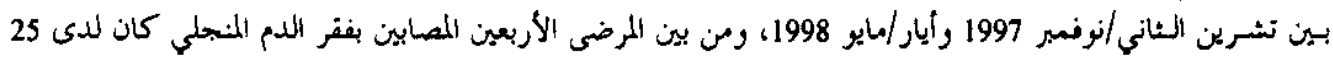

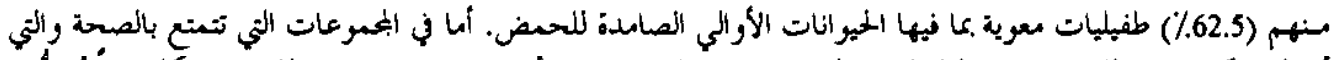

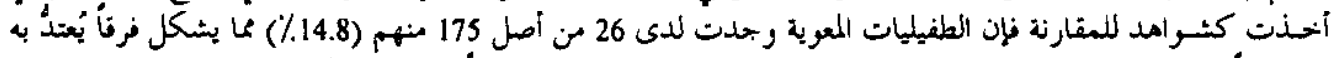

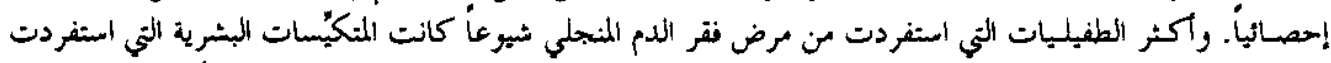

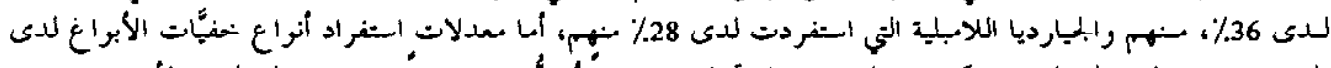

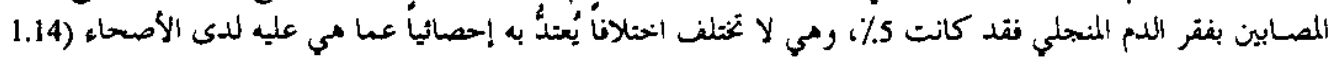

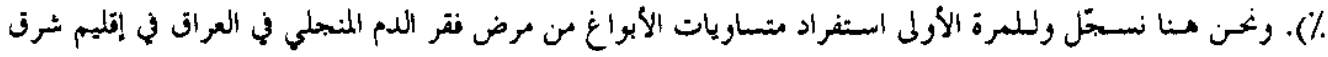
المتمر سط.

ABSTRACT Stool samples were obtained from individuals admitted to three hospitals in Basra during November 1997-May 1998. Of 40 patients with sickle-cell anaemia, $25(62.5 \%)$ had parasitic infections. In the apparently healthy comparison group, 26 of 175 individuals (14.8\%) had intestinal parasitic infections, a statistically significant difference. The most common intestinal parasites isolated in the sickle-cell patients were Blastocystis hominis (36\%) and Glaroia tambila (28\%). I he isolation rate of Cryptosporidium species in sickle-cell patients (5\%) was not significantly different from that in apparently healthy individuals (1.14\%). We report for the first time the isolation of isospora bellifrom a sickle-cell patient in Iraq and the Mediterranoan region.

Les parasites intestinaux, y compris Cryptosporidium spp., chez des patients iraquiens atteints de drépanocytose

RESUME Des échantillons de selles ont été recueillis chez des personnes admises dans trois hôpitaux de Bassora de novembre 1997 à mai 1998. Sur 40 patients atteints de drépanocytose, $25(62,5 \%)$ avaient une parasitose intestinale. Dans le groupe témoin de patients apparemment en bonne sante, 26 des $1 / 5$ sujets $(14,8 \%)$ avajent une parasitose intestinale, une difference statistiquement significative. Les parasites les plus couramment isolés chez les patients atteints de drépanocytose étaient Blastocystis hominis ( $36 \%$ et Giardia lamblia (28\%). Le taux d'isolement d'espècos do Cryptosporidium choz los sujots atteints de drépanocytose $(5 \%)$ n'était pas significativement différent de celui chez les sujets apparemment en bonne santé $(1,14 \%)$. Pour la première tois, nous signalons l'isolement de isospora bellichez un patient atteint de drépanocytose en Iraq et dans la région de la Méditerranée.

'Department of Microbiology. College of Medicine, University of Basra, Basra, Iraq.

Received: 31/10/00; accepted: 03/04/01

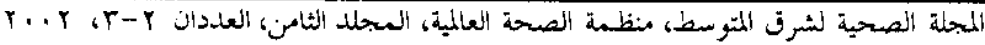




\section{Introduction}

Sickling disorders are among the most common abnormalities affecting the stability and integrity of red blood cells. They comprise a group of genetic diseases resulting from homozygosity of haemoglobin $\mathrm{S}$ (HbS), double heterozygosity of $\mathrm{HbS}$ and orher abnormal haemoglobins, and the presence of $\mathrm{HbS}$ in association with various types of thalassaemias [1]. $\mathrm{HbS}$ is the most common variant of normal adult hatemoglobin (HbA). The phenotypic frequency for the $S$ gene is $10 \%-45 \%$ in black Africans, $8 \%-12 \%$ in Africant-Americans and African-Caribbean populations, and $5 \%-30 \%$ in Greece, Turkey, and parts of Indla and South-East Asia [2]. Individuals, particularly children, with such disorders have an increased susceptibility to bacterial infections, and this is one of the main causes of morbidity and mortality [3-8].

Cryptosporidium species have been implicaled as anl eliological agent in persistent diarrhoea, with significant morbidity and mortality in those with chronic diseases $[9,10]$. Intestinal parasitic infections are relatively common in the developing countries, including Iraq [11].

In the absence of previous teports, we aimed to examine the prevalence of such parasitic species in patients with sickle-cell anaemia compared with individuals with no sickle-cell disorder.

\section{Methods}

The study involved 40 patients ( 20 males and 20 females) with sickle-cell anaemia who had been admitted to Abu Al-Khasib General Hospital, Basra General Hospital or Basra Teaching Hospital for blood transfusion or recovery from crisis. Their ages ranged from 2 years to 60 years with a mean of $21.6 \pm 17.4$ years. As a comparison group, 175 apparently healthy individuals (105 males and 70 females) with no episodes of diarrhoea in the previous 2 months were studied. Their mean age was $23.7 \pm 20.1$ year.

Single stool samples were collected from these 215 individuals from November 1997 to May 1998. All samples were screened for the presence of non-acid fast parasites by direct smear method and the Ritchie formalin-ether sedimentation concentration method [12]. Faecal smears were prepared from the sediment and stained by the modified Ziehl-Neelsen method [12] for the detection of red-pink oocysts of acid-fast parasites (Cryptosporidium, Cyclospora and Isospora species).

The SND (standard normal deviate) test was used as a test of significance. Differences were recorded as significant when $P>0.05$. The odds ratio and $95 \%$ confidence intervals of the odds ratio were estimated for a single $2 \times 2$ table (to determine whether there was a crude disease exposure association).

\section{Results}

Table 1 shows the distribution of parasitic infections in the sickle-cell patients and the comparison group. Of the 40 sickle-cell patients examined, $25(62.5 \%)$ were found to be infected with intestinal parasites (including Cryptosporidium species). In the comparison group only $26(14.8 \%)$ individuals were infected (Table 1). The difference was statistically significant ( $\mathrm{SND}=6.44, P$ $<0.01$, odds ratio $=9.55$ ). Of the 40 sicklecell patients, only $2(5.0 \%)$ were found to be only excreting Cryptosporidium oocysts. The Cryptosporidium infection rate among the comparison group was $1.14 \%$ 
Table 1 Distribution of parasitic and Cryptosporidium infections among the sickle-cell patients and an apparently healthy comparison group according to age

\begin{tabular}{|c|c|c|c|c|c|c|c|c|c|c|}
\hline \multirow{3}{*}{$\begin{array}{l}\text { Age } \\
\text { group } \\
\text { (years) }\end{array}$} & \multicolumn{5}{|c|}{ Sickle-cell patients } & \multicolumn{5}{|c|}{ Healthy comparison group } \\
\hline & \multirow[t]{2}{*}{$\begin{array}{l}\text { No. } \\
\text { examined }\end{array}$} & \multicolumn{2}{|c|}{$\begin{array}{c}\text { Cryptosporidium } \\
\text { intection }\end{array}$} & \multicolumn{2}{|c|}{$\begin{array}{l}\text { Parasitic } \\
\text { infection }\end{array}$} & \multirow[t]{2}{*}{$\begin{array}{l}\text { No. } \\
\text { examined }\end{array}$} & \multicolumn{2}{|c|}{$\begin{array}{l}\text { Cryptosporidium } \\
\text { infection }\end{array}$} & \multicolumn{2}{|c|}{$\begin{array}{l}\text { Parasitic } \\
\text { infection }\end{array}$} \\
\hline & & No. & $\%$ & No. & $\%$ & & No. & $\%$ & No. & $\%$ \\
\hline$<6$ & 10 & 1 & 1.0 & 7 & 70.0 & 60 & 1 & 1.7 & 9 & 15.0 \\
\hline $6-15$ & 8 & 0 & 0 & 7 & 87.5 & 20 & 0 & 0 & 5 & 25.0 \\
\hline $16-25$ & 8 & 0 & 0 & 5 & 62.5 & 20 & 0 & 0 & 4 & 20.0 \\
\hline $26-35^{\circ}$ & 5 & 0 & 0 & 2 & 40.0 & 17 & 0 & 0 & 4 & 23.5 \\
\hline $36-45$ & 4 & 0 & 0 & 2 & 50.0 & 25 & 0 & 0 & 2 & 8.0 \\
\hline $46-55$ & 3 & 1 & 33.3 & 1 & 33.3 & 18 & 0 & 0 & 1 & 5.6 \\
\hline $50-05$ & 2 & 0 & 0 & 1 & 50.0 & 15 & 1 & 6.7 & 1 & 6.7 \\
\hline Total & 40 & 2 & $5.0^{\mathrm{a}}$ & 25 & $62.5^{b}$ & 175 & 2 & $1.14^{\mathrm{a}}$ & 26 & $14.8^{b}$ \\
\hline
\end{tabular}

SND $=1.77 . P>0.05$

${ }^{\circ} S N D=6.44, \mathrm{P}<0.01$, odds ratio $=9.55$.

but the difference was not statistically significant (SND $=1.77, P>0.05$ ).

Table 2 shows the distribution of the different parasitic infections in the sicklecell and comparison groups by sex. The most common parasites identified in the sickle-cell group were Blastocystis hominis (36\%) and Giardia lamblia (28\%). A single case of $I$. belli was diagnosed in a male sickle-cell patient. The infection rate was

\begin{tabular}{|c|c|c|c|c|c|c|}
\hline Parasites & $\begin{array}{l}\text { Sickle-ce } \\
\text { Male }\end{array}$ & $\begin{array}{l}\text { Il patients } \\
\text { Female }\end{array}$ & $\begin{array}{c}(n=40) \\
\text { Total }\end{array}$ & $\begin{array}{c}\text { Healthy comp } \\
\text { Male }\end{array}$ & $\begin{array}{l}\text { arison gr } \\
\text { Female }\end{array}$ & $\begin{array}{l}\text { oup }(n=176) \\
\text { Total }\end{array}$ \\
\hline \multicolumn{7}{|l|}{ Single infection } \\
\hline Cryptosporidium species & 1 & 1 & 2 & - & - & - \\
\hline Isospora belli & 1 & - & 1 & - & - & - \\
\hline Blastocystis hominis & 5 & 4 & 9 & 9 & 2 & 11 \\
\hline Giardia lamblia & 5 & 2 & 7 & 3 & 0 & 3 \\
\hline Entamoeba histolytica & 1 & 2 & 3 & 1 & 1 & 2 \\
\hline Enterobius vermicularis & - & 1 & 1 & 2 & 4 & 6 \\
\hline Trichiuris trichiura & - & 1 & 1 & - & - & - \\
\hline Taenia saginata & - & 1 & 1 & - & - & - \\
\hline \multicolumn{7}{|l|}{ Mixed infection } \\
\hline Cryptosponidium + B. hominis & - & - & - & 1 & 1 & 2 \\
\hline B. hominis + G. lamblia & - & - & - & 1 & - & 1 \\
\hline B. hominis + E. vermicularis & - & - & - & - & 1 & 1 \\
\hline Total no. (\%) & $13(32.5)$ & $12(30.0)$ & $25(62.5)$ & $17(9.7)$ & $9(5.1)$ & $26(14.8)$ \\
\hline
\end{tabular}

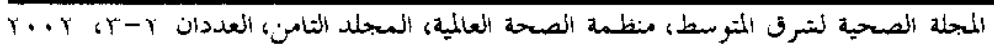


similar in both males and females within each group (Table 2).

\section{Discussion}

Our results show that patients with sicklecell anaemia are much more susceptible to both acid- and non-acid-fast parasitic infections in comparison with the non-sicklers (odds ratio $=9.55$ ). Patients under 25 years were particularly affected by intestinal parasites, possibly due to the severity of the sickle-cell anaemia in this age group.

Thus parasitic infections, including cryptosporidiosis, can be added to the long list of bacterial infections, such as pneumonia, osteomyelitis, meningitis, septicaemia, typhoid fever and urinary tract infections $[1-8,13-15]$ to which sickle-cell patients are vulnerable. Such infections can be considered a main cause of morbidity and mortality and may be life-threatening to those with chronic disease such as sickle-cell anaemia or in individuals with certain immunological conditions $[1,2,16]$.

To our knowledge, we report the first cases of cryptosporidiosis and isosporiasis among sickle-cell patients in Iraq and the Mediterranean region. The combination of formalin-ether sedimentation and modified acid-fast stain methods clearly provides high sensitivity and specificity [10].

The rate of parasitic infection found here is of significance from the public health point of view, and the actual rate is likely to be higher due to the intermittent shedding of acid-fast oocysts [17] and $G$ lamblia [18].

Bacterial and parasitic infections are a major presenting manifestation in sicklecell patients [19]. The mechanisms contributing in the increased vulnerability to infection are splenic dysfunction, decreased IgM levels and a defective alternative complement pathway [20]. The spleen has a dual role in infection: biological filtrating and plagocytosis of microurganisms, and production of specific IgM antibodies and tuftsin [2]. Some sickle cells cause blockage or the vessels supplying blood to an organ, leading to hypoxia of the organ and resultant cell death and progressive scarring. This furms an ideal site for the growth of certain bacteria and leads to an increased susceptibility to infections [1]. These palients lave also been shown to have decreased levels of functionally active factor $B$, due to an increased rate of factor B catabolisn $[21,22]$. Inadequate levels of $\mathrm{C}_{3} \mathrm{~b}$ lead to deficient opsonic activity and inefficient phagocytosis [2].

Our observations in sickle-cell patienls suggest that both acid-and non-acid-fast intestinal parasites should be considered in the differential diagnosis of undiagnused chronic diarrhoea in order to arrive at the proper treatment. Management of complications, including infections, will improve the quality of life of such patients.

\section{References}

1. Warsy AS, El-HazmI MAF. Bacterial infections and the sickling disorders. $A$ review. Saudi medical journal, 1987, $8(3): 228-37$.

2. Onwabalili JK. Sickle-cell disease and infection. Journal of infection, 1983, 7:220.
3. Barrett-Connor E. Bacterial infections and sickle-cell anemia: an analysis of 250 infections in 166 patients and a review of the literature. Medicine (Baltimore), 1971, 50:97-112.

4. Seeler RA, Metzger W, Mufson MA. Diplococcus pneumoniae infection in children 
with sickle-cell anemia. American journal of disease in childhood, 1972, 123:8-10.

5. Murtaza LN et al. Admissions to hospital of children with sickle-cell anaemia: a study in London. British medical journal, 1981, 282:1048-51.

6. Henneberger PK, Galaid El, Marr JS. The descriptive epidemiology of pneumococcal meningitis in New York City. American journal of epidemiology, 1983, 117:484-91.

7. Nelson JD. Bone and joint infections. Pediatric infectious diseases, 1983, 2:45-50.

8. Thomas AN, Pattison C, Serjeant GR. Causes of death in sickle-cell diseases in Jamaica. Brilish meaical journal, $1982,285: 633-5$.

9. Flanigen T. Cryptosporidiosis and coccidial infection. In: Nelson WE et al., eds. Nelsons textbook of pediatrics, 15th ed. Philadelphia, WB Saunders Company, 1996:968-9.

10. Ali NH. Prevalence of cryptosporidiosis with zoonotic aspect [MSc. Thesis]. Basra, College of Medicine, University of Basra, 1998.

11. Mahdi NK. Jassim AH. Intestinal parasitic infections of primary-school children in three regions of southern Iraq. Medical journal of Basrah University, 1987, 6:55-61.

12. Markell EK, Voge M, John DT. Medical parasitology, 6th ed. Philadelphia, WB Saunders Company, 1986:331 48 .

13. Mcintosh SY, Ritchey AK, Pearson HA. Fever in young children with sickle-cell disease. Journal of pediatrics, 1980 , 96:199-204.

14. Powers $D$ et al. Pneumococcal septicemia in children with sickle-cell anemia.
Changing trend of survival. Journal of the American Medical Association, 1981, 245:1842.

15. Landesman SH, Rao SP, Ahoukai VI. Infections in children with sickle-cell anemia. Special reference to pneumoccocal and salmonella infection. American journal of pediatrics and hematological oncology, 1982, 4:407-18.

16. Addiss DG, Juranek DD, Sehartz DA. Cryptosporidiosis. In: Horsburgh CR, Nelson AM. eds. Pathology of emeroino infections. Washington DC, American Society of Microbiology, 1997:243-56.

17. Epenoer KL ot al. Cryptooporidiosis in HIV-infected persons: prevalence in a New York City population. International journal of infectious diseases. 1997. $1(4): 217-21$.

18. Danciger M, Lopez M. Numbers of Giardia in fooos of infoctod childron. Amorican journal of tropical medicine and hygione, 1975, 24:237-42.

19. Thomas R. Slckle-cell disease: ways to reduce morbidity and mortality. Postgraduate medicine, 1987, 81:265-8, 273-80.

20. Gavrilis P, Rothenberg SP, Guy R. Correlation of low serum $\lg M$ levels with abserice of functional splenic tissue in sickle-cell disease. American journal of medicine, 1974, 57:542-5.

21. Wilson WA, Hughes GR, Lachmann PJ. Deficiencies of factor $B$ of the complement system of sickle-cell anaemia. British medical journal, 1976, 1(6006): 367-9.

22. Wilson WA, Thomas EJ, Sissons JG. Complement activation in asymptomatic patients with sickle-cell anaemia. Climical and experimental immunology, $1979,36: 130-9$. 